\title{
Unaccompanied asylum-seeking children: Whose perspective?
}

\author{
Ulrika Wernesjö \\ Journal Article
}

\section{Tweet}

N.B.: When citing this work, cite the original article.

Original Publication:

Ulrika Wernesjö , Unaccompanied asylum-seeking children: Whose perspective?, Childhood, 2012. 19(4), pp.495-507.

http://dx.doi.org/10.1177/0907568211429625

Copyright: SAGE Publications (UK and US)

http://www.uk.sagepub.com/home.nav

Postprint available at: Linköping University Electronic Press

http://urn.kb.se/resolve?urn=urn:nbn:se:liu:diva-131928

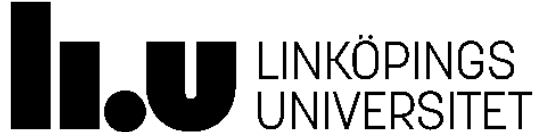




\title{
Unaccompanied asylum-seeking children: Whose perspective?
}

\author{
Ulrika Wernesjö \\ Uppsala University, Sweden
}

\begin{abstract}
Abs tract
Recent years have seen increasing attention being paid to unaccompanied asylum-seeking children. This article provides an overview of research in the field and its implications for an understanding of these children as a particularly vulnerable category. The existing research focuses primarily on investigating the children's emotional well-being from psychiatric and medical perspectives. Moreover, in these studies such emotional problems tend to be linked to previous and current traumatic experiences, in particular separation from their parents. By contrast, this article suggests that a critical need exists for research on unaccompanied children's life situations based upon exploration of their own perspectives.
\end{abstract}

\section{Keywords}

agency, emotional health, migration, unaccompanied children, vulnerability

\section{Introduction}

In recent years there has been growing attention to unaccompanied asylum-seeking children in the European Union member states. In many ways, unaccompanied children are conceived as children 'out of bounds' (Chin, 2003) and beyond the realm of what is considered a normal childhood. They have travelled out of their country of origin and they have been separated from their parents (Halvorsen, 2002). Despite the fact that unaccompanied children have received attention in political debates and policy-making, research concerning them remains limited. In the research that does exist there is a general agreement that unaccompanied children are a particularly vulnerable group as minors, as children separated from their parents and as refugees and asylum-seekers, and when describing their situation central themes are loss, uprooting, separation and trauma.

The aim of this article is to present an overview of research on unaccompanied children and discuss the implications of existing research for understanding this category of children. The existing research on unaccompanied children is primarily focused on their emotional well-being and they are generally understood as being in a particularly vulnerable position. What is the focus of attention in research about unaccompanied asylumseeking children in terms of their well-being and situation in the host country? In what ways do researchers understand unaccompanied children and how are unaccompanied children as a category described? With what factors is their vulnerability associated? With these questions in mind, are there alternative or additional approaches to the investigation of the life situation of these children and young persons? If so, how might such approaches benefit our unders tanding of this research is sue?

This article first gives a brief presentation of existing research on unaccompanied children and in particular delineates the selection of the research upon which this article is based. The article proceeds to discuss how emotional problems and psychiatric symptoms among unaccompanied children have been investigated in the research selected. Thereafter, it examines the ways in which experiences of trauma - primarily in the past but also in the present - including separation from parents and care-givers have been explored and related to emotional problems among unaccompanied children. Finally, the implications of existing research are explored in relation to the way unaccompanied children are constructed as a category. Also at the heart of this analysis is the way in which the children's participation and own perspectives on their situation are often restricted in research. By contrast, from a sociological perspective, this article advocates the potential for studying unaccompanied children and their situations by exploring their own perspectives and experiences in the host country to a larger extent than has been done so far. What is their situation like from their own point of view and which issues do they themselves focus on?

\section{Who are the unaccompanied children?}

In research and policy documents, unaccompanied children are categorized as a specific category of migrants and asylum-seekers since they are minors and separated from their parents or care-givers. However, they are a heterogeneous category not only in terms of gender, age, ethnicity and religion, but also in terms of their past experiences and present life situations.

The term unaccompanied is used frequently in research and policy documents. So, what does the term 
unaccompanied child represent in such documentation? Being unaccompanied does not necessarily mean that the children, or minors, travel or enter the host country alone, but rather that they have been separated from their parents. According to the United Nations Refugee Agency an unaccompanied child is:

[A] person who is under the age of eighteen ... and who is separated from both parents and is not being cared for by an adult who by law or custom has responsibility to do so. (UNHCR, 1994: 121)

In research both the terms unaccompanied and separated are used when discussing minors who have travelled outside their country of origin and are seeking as ylum without their parents or guardians. The Separated Children in Europe Programme 1 (SCEP) prefers (as its name suggests) the term separated rather than unaccompanied, since it better defines the essential problem for these children, i.e. that they are separated from their parents, care-givers or legal guardians, and suffer from this situation (SCEP, 2004). However, there are other categories of minors, who are also separated from their parents and care-givers. Since this article is concerned with the specific category of children who share a migration experience, I suggest that unaccompanied children is an appropriate term because it points to that specific experience.

\section{Selection of research}

Inward migration, and the asylum-seeking process in particular, is highly regulated within European Union member states and much of the 'Global North'2 more generally. Furthermore, the specific political and social context has an impact on the reception of unaccompanied children and on their life situations in exile. The Norwegian sociologist Ketil Eide (2005) has classified research on unaccompanied children in Norway into three main categories. The first is organization studies focusing on the reception of unaccompanied children (e.g. Kohli, 2005); the second is studies with a focus on children's rights (e.g. Bhabha, 1999); the third is psychosocial studies of well-being, life situations and emotional problems among unaccompanied children (e.g. Derluyn and Broekaert, 2007; Hodes et al., 2008; Sourander, 1998). I suggest that the same range of categorizations can be applied at an international level as well, with the addition of studies that map unaccompanied children's background experiences and child-s pecific grounds for asylum (e.g. Ayotte, 2000; Hopkins and Hill, 2008). Considering that this overview primarily concerns research on unaccompanied children themselves and not the institutional arrangements surrounding them, I concentrate on psychosocial studies and on research that concentrates on unaccompanied children and their specific situation in different ways. The basis of this article is thus academic literature on unaccompanied asylum-seeking and refugee children. The following keywords in the search process have been used: unaccompanied or separated, asylum-seeking or refugee children, young persons, adolescents. The selection criteria for the literature surveyed were defined in line with the aim of this article (as outlined earlier) and relate to a broad range of research fields including child psychiatry, child welfare, educational science, law, nursing science, social work, sociology, psychology and public health.

\section{Emotional well-being and psychiatric symptoms among unaccompanied children}

As mentioned previously, there is a general agreement among researchers that unaccompanied children are a particularly vulnerable category of asylum-seekers (e.g. Bean et al., 2007; Derluyn and Broekaert, 2007; Hodes et al., 2008; Sourander, 1998). Bearing in mind that studies on unaccompanied children are primarily focused on their emotional health or lack thereof, the research addressed within this section is primarily conducted within individual-oriented disciplines that focus on psychopathology. Moreover, it bases its research on self-report questionnaires and similar standardized quantitative methods. However, in contrast to this general trend, there is a contribution by Chase et al. (2008) that, with a qualitative approach, focuses on emotional well-being from the perspectives of the young persons and discusses the young persons' own thoughts on psychiatric diagnosis.

In research on asylum-seekers and refugees in general the main focus is on emotional problems, trauma and psychiatric symptoms and on difficulties in their host country (Chatty et al., 2005). There are a number of studies that investigate the prevalence of psychiatric symptoms such as post-traumatic stress disorder(PTSD), depression and anxiety (e.g. Almqvist, 1997; Hjern and Angel, 2000). In a Belgian study, between 37 and $49 \%$ of the unaccompanied children who participated were identified as suffering with psychiatric diagnoses such as depression, anxiety and PTSD (Derluyn and Broekart, 2007). The most common symptoms among unaccompanied asylum-seeking children in a Finnish study are said to be related to psychiatric diagnosis (Sourander, 1998). Moreover, in a Swedish psychologicalstudy, all of the unaccompanied young persons living in a group home were said to suffer from the one or several psychiatric symptoms (Brendler-Lindqvist and Larsson, 2004). Symptoms such as sleeping disorder, concentration difficulties and mood swings have been distinguished as regular among the unaccompanied minors (Brendler-Linqvist and Larsson, 2004; Chase et al., 2008). Lack of appetite, suicidal thoughts, depression and post-traumatic stress symptoms were also prevalent (Brendler-Lindqvist and Larsson, 2004; Sourander, 1998). In another study, Bean et al. (2007) compared the prevalence of emotional and psychiatric 
problems among unaccompanied children and asylum-seeking children who were accompanied by their parents. They suggest that the former are at a higher risk than the latter of developing emotional and behavioural problems. According to Hodes et al. (2008) unaccompanied children also suffer to a higher degree from post-traumatic symptoms in comparison to accompanied children. In line with results such as these, Derluyn and Broekaert conclude that 'Being unaccompanied is an important risk factor for the emotional well-being of refugee children and adolescents' (2007: 141).

In the research surveyed, being unaccompanied as an asylum-seeking or refugee child is intimately linked to an increased risk of emotional problems and psychopathology. The focus is on identifying problems and on locating these at the individual level. In this way unaccompanied children are categorized as particularly in need of care and intervention. The focus on mental health and on psychiatric diagnosis - in this case in the UK - is criticized by Chase et al. (2008), who caution that understandings of these concepts may differ and stress the need for health services to take that into account when working with unaccompanied children and young persons. In their study, the young persons stated that they refrain from the use of the term mental (un)health, equating it with being 'crazy' or 'insane' (2008: 47ff.). Even though culturally specific understandings should not be overstated, at the risk of essentialism, I would argue that Chase et al.'s point should also be taken into account in research with regards to ethics. For there may be some risk that research could contribute to skewed or stigmatizing conceptions by solely focusing on problems and vulnerability (Alver and Øyen, 1997).

As already noted, unaccompanied children constitute a heterogeneous category in terms of gender, ethnicity, previous experiences, countries of origin and host countries, etc. In the research surveyed here, certain categories who are at a higher risk of developing emotional problems - and therefore particularly vulnerable - are distinguished according to (female) gender (Derluyn and Broekaert, 2007), age (Hodes et al., 2008; Sourander, 1998) and experiences of several traumatic events (Derluyn and Broekaert, 2007). When interpreting the findings of why certain categories of persons are more at risk, both Derluyn and Broekaert and Sourander refer to their background experiences, while Hodes et al. suggest that the specific social and political context in the host country may also be of relevance. The findings from the studies by Hodes et al. (2008) and Sourander (1998) differ regarding the impact that age has on emotional health, which leads the authors to draw different conclusions. Whereas Sourander found that children under the age of 15 had more severe emotional problems compared to older children, Hodes et al. found instead that increasing age was as sociated with inc reased levels of post-traumatic stress symptoms. Hodes et al. suggest that transition into adulthood poses particular challenges for unaccompanied children. It entails both a transition to more independent living and a higher degree of personal responsibility, while at the same time raising uncertainty concerning their future legal status in Great Britain. An alternative explanation can be suggested, one that is not found in the research reviewed. For, it may also be that older children have more experiences that are potentially traumatizing because they have lived a longer life.

Given that unaccompanied asylum-seeking children are considered to be a particularly vulnerable category, the question concerning how their emotional health develops should take a long-term perspective. This is considered important, yet has not been explored to any great extent. However, there are a few follow-up studies that investigate these issues using qualitative methods (Hessle, 2009; Luster et al., 2010; Wallin and Ahlström, 2005) or a combination of qualitative and quantitative methods (Eide, 2000). None of these studies are entirely concentrated on emotional health, but rather on the young person's life situations and successfuladaption in a wider perspective The findings from the two Swedish studies (Hessle, 2009; Wallin and Ahlström, 2005) show that most of the research participants felt content with their life situations in the host country, and had begun adapting to their new life. However, establishing a life in exile entails both possibilities and risks, according to Hessle (2009). Furthermore, some participants in Wallin and Ahlström's study stated that they felt lonely and some of them suffered from depression and PTSD. Drawing on the perspectives of Sudanese refugee boys living in the US and of their foster parents, Luster et al. (2010) show how successful adaption is linked with education and school performance as well as balancing life adaption in the host country with maintaining connections with Sudan. Eide's (2000) Norwegian study also focused upon school performance, together with occupation, among other issues. In addition, his research also places emphasis on the significance of social bonds and relationships for unaccompanied children's development, particularly with care-givers but also others. Moreover, Eide highlights that, even though unaccompanied children and young persons are a heterogeneous category, the structural conditions that they face in the host country are the same, or at least similar.

\section{A particularly vulne rable category with experiences of trauma, dis ruption and loss}

The main suggestion in the research discussed in the previous section is that unaccompanied children are at a higher risk of developing emotional problems, and that these problems are consequences of their vulnerability. In the following I investigate the main factors that are especially emphasized, namely that unaccompanied children are particularly vulnerable because of their experiences, as asylum-seekers and as separated from their parents. 


\section{Unaccompanied children's previous and present experiences}

Research on unaccompanied children puts emphasis on their shared experiences of multiple losses and traumatic experiences. However, this has not been investigated to any great extent. In this section I discuss what is said of their particular experiences in the research surveyed. The focus of concern is mainly background experiences from their countries of origin and from their migration, although some attention is also given to their situation and experiences in the host country. In order to describe what kinds of experiences young persons carry with them, mappings of their previous experiences are often presented. Nevertheless, these mappings are rarely the centre of attention; rather they are a way of describing unaccompanied children's particularly vulnerable situation and the support needed. There is however a body of research that particularly focuses on pre-flight experiences (e.g. Ayotte, 2000; Thomas et al., 2004). Death of family members, persecution, forced recruitment, war, trafficking, living in hiding, experiencing or witnessing violence, experiences of sexual violence and being imprisoned or detained are according to a number studies identified as background experiences (Ayotte, 2000; Goodman, 2004; Sourander, 1998; Thomas et al., 2004). The experiences range from personalexperiences, to witnessing traumatic events and living in a country torn by internal conflict and poor humanitarian conditions (e.g. Brendler-Lindqvist and Larsson, 2004). Experiences such as these, together with the ambition to get a better life through education, are identified as the primary reasons for flight according to a British study by Thomas et al. (2004).

The migration experience for unaccompanied children and young persons is characterized as a journey of uncertainty. According to research, the children and young persons seldom migrate by themselves, rather they travel together with an adult (an 'uncle'), often ignorant of both the route and final destination (Hopkins and Hill, 2008). Moreover, they were not only left uninformed during their migration, but also excluded from the decision making process prior to the migration. Instead it was most often their parents, or other adult (male) re latives who made the decision (Hopkins and Hill, 2008; Sourander, 1998). Hence, the children and young persons were not adequately informed or included in the decision-making even though the decision involved radical changes in their lives (see Hart, 1992). However, by solely focusing on the lack of participation there is a risk that the young persons' own agency, in cases where they themselves have made the decision to leave, is overlooked. Moreover, this raises questions regarding the relationship between agency and vulnerability. In particular, one needs to consider whether recognition of the young person's active part in the decision-making to leave might have an impact on seeing them as solely being in a vulnerable position.

The impact of the asylum-seeking process and unaccompanied children's position in the host country has not been explored to any great extent. However, there has been some discussion on the life situations of unaccompanied children in the host country, and it is suggested that the asylum-seeking process itself can be a potentially traumatizing experience for unaccompanied children 3 (Bhabha, 1999; Thomas and Byford, 2003). Life in waiting for a final decision on the asylum application is characterized as filled with uncertainty and the bureaucratic processes can be hard to understand (Sourander, 1998). It is also stated that the care and reception they receive is not always adequate (Derluyn and Broekaert, 2007, 2008; Sourander, 1998). Concerning the life situation in the host country, Hodes et al. (2008) suggest that there may be unidentified stress factors - such as social isolation, uncertainty, language difficulties and other unidentified stressors connected to experiences as as ylum-seekers - that pose challenges for unaccompanied children. Derluyn and Broekaert draw on psychological research about the risk of acculturative stress for persons; in this case children and young persons who migrate to a society which is culturally, socially and linguistically different. They discuss how these young persons have to balance between the two societies and thereby risk feeling loyalty conflicts with family members and the home country (Kohli, 2002, cited in Derluyn and Broekaert, 2008). When the situation in the host country is discussed in research studies, there is generally an absence of consideration of racism and discrimination to which these children and young persons may have been subjected. Even though experiences of racism are sometimes mentioned, they are rarely investigated in the literature. Instead, experiences of refugees and asylum-seekers and their encounter with the host country are discussed within a frame of acculturation or social integration. One exception to this, a study on unaccompanied children and young persons in east London, suggests that they had experienced racism, inequalities and processes of being othered on a daily basis (Sinha et al., 2008). In contrast to most other studies on unaccompanied children, this study is also particularly focused on the unaccompanied children's and young persons' own perspectives concerning their lives.

\section{Separation and its consequences}

In cases where children have been sent away by their parents, the separation occurred at the time of the migration. For other children, the separation happened before the migration as a consequence of war, persecution or due to the parent's death, imprisonment or disappearance (Brendler-Lindqvist and Larsson, 2004; Hopkins and Hill, 2008; SCEP, 2004). This section deals with how the absence of parents and care-givers is discussed in the research selected. In addition, it focuses on what parents are considered to provide for their children and thereby what unaccompanied asylum-seeking children are lacking. Separation - in particular from parents, but also from other 
family members and friends - is considered as being especially problematic for the emotional well-being and life situation of unaccompanied children and young persons. Yet, the separation itself is rarely the main focus of attention in the research reviewed here. The impact of separation is generally presented in the research reviewed as a background, in which the researchers draw on previous research and psychological theories about the significance of parents and the consequences that separation signifies for children and young persons. Alongside such approaches, there are instances where cultural understandings of family and social net work are drawn upon by researchers. For instance it is suggested that separation might be especially aggravating for this category of children since they often come from more collectivistic cultures (e.g. Derluyn and Broekaert, 2008). Such a suggestion assumes that these children have had intimate family and kin relations before their flight. It can also be criticized for generalizing them as a homogeneous category of ethnic others. Moreover, this naturalized conception of children as parts of a (biological) family can also be an expression of the familialization of children (Alanen, 1992: 91ff.). For instance, a book that is referred to in a number of studies relevant to this discussion (e.g. BrendlerLindqvist and Larsson, 2004; Derluyn and Broekaert, 2008) is War and Children (Freud and Burlingham, 1943). This book is based on research on children, up to 10 years of age, who were evacuated from London during the Second World War. Freud and Burlingham argue that the presence of parents is essential for children's emotional well-being, even in cases when the parents themselves are traumatized, and claim that children who have been separated from parents will suffer psychologically even in a long-term perspective. These findings have impacted heavily on later research on child-parent relations and separations. Although there seems to be a general agreement on the significance that parents have on children's lives, it can be debated whether there are circumstances where it is better for the child, and even essentialfor his or her survival, to be separated from the parents (e.g. Lomfors, 2006). Moreover, as Rutter (2002) demonstrated some time ago, the separation from parents and care-givers is only one of many factors that may have significance for children's development in a long-term perspective.

In the research surveyed I have distinguished three ways that unaccompanied children are understood as suffering from the separation. The separation is considered to entail emotional loss, loss of sense of security and support and also loss of role models or socialization agents. The different understandings are often overlapping. However, I suggest that making distinctions opens up a space for elaborating on what children and young persons who are separated from their parents are lacking and whether other social relations and significant others can fill the position of absent parents. I now turn to a consideration of each of these three ways of conceptualizing the impact of separation.

First, as noted, separation from parents involves an emotional loss for unaccompanied children and young persons. An emotional bond between parents and children is presupposed and seen as of great importance in the research surveyed. For children and young persons whose parents had been killed or had disappeared, the separation and emotional loss is considered as a particularly traumatizing experience (Brendler-Lindqvist and Larsson, 2004) and an emotional loss that unaccompanied children and young persons suffer from and have to cope with.

Second, it concerns the support and protection parents are supposed to provide for their children. This involves having someone who provides protection and care and a sense of security. Moreover, this can entail having an adult to trust in, to whom one can address questions and with whom to talk about experiences. In the context of previous experiences of war, disruption and forced migration being considered risk factors for emotional wellbeing, the research surveyed argues that unaccompanied children are at a higher risk since parents are a major source of support (Derluyn and Broekaert, 2007, 2008) and protection (Sourander, 1998). Migration processes and traumatic experiences in the past and present are considered as disruptions to everyday life. From such a point of view it is suggested in the research that refugee and asylum-seeking children are particularly vulnerable and in need of extra support, care and a sense of security. In this was an intimate link is made between such support and parents and since unaccompanied children do not have their parents present it is emphasized that there is a lack of this form of support in their lives.

Third, most unaccompanied asylum-seeking children who arrive and seek asylum are teenagers between ages 13 and 17. In psychological developmental theory it is suggested that adolescence is a particularly vulnerable phase of life for young persons on their way to adulthood, and is characterized by identity formation. From such a perspective, the teenager is striving to gain independence, at the same time as still being in need of the parents for guidance and support (e.g. Wrangsjö and Winberg Salomonsson, 2007). In this process, parents are portrayed as not only sources of support, but also as important role models for their children. In certain sociological socialization theories emphas is is also given to the family as the primary location of socialization, and to parents who are considered to be the primary socialization agents (Wyness, 2006: 129). Some sociological research on socialization and socialization processes has also adopted developmental perspectives on children and young persons. This, in turn, has been critiqued by Qvortrup (1985) for adopting a psychological discourse, and thereby not contributing to sociological theory. The argument is that since unaccompanied children and young persons do not have their parents present, they also may lack sufficient role models or significant others. From a psychological developmental perspective this might entail a risk for them. Thereby it is suggested that unaccompanied children are particularly vulnerable since they - at such a young age - are dealing with traumatic experiences at the same 
time as they have to cope with new living situations in an unfamiliar society without the support and guid ance of their parents (e.g. Derluyn and Broekaert, 2007). It is stressed in the research surveyed that unaccompanied children and young persons are in need of adults they can trust in order to help them cope with their life situation. Such adults are also seen as potentially ameliorating the reception system (e.g. Derluyn and Broekaert, 2007; Hopkins and Hill, 2008). Nevertheless, even though parents tend to be seen as the best pers ons to pro vide care and guidance for the children, in this way the literature also allows for the pos sibility that other adults are able to fill such a position for these young persons.

\section{Coping strategies and inner resources}

There is a tendency in these studies to focus on emotional problems arising from hard ship, traumatic experiences and separations in the past and present - rather than on how unaccompanied children and young persons thems elves deal with emotional problems in terms of coping and resilience. In Sourander's (1998) study, emotional and behavioural problems were more frequent among the youngerchildren. These results led him to suggest that older children possess more internal resources to cope with their experiences and separations (1998: 724). What these internal resources are and in what ways these children cope are not investigated, which would suggest that research on unaccompanied children may tend to be concentrated on their vulnerability rather than on their own resources and agency. However, there is some research that explores coping strategies among unaccompanied children in the UK (Chase et al., 2008) and among Sudanese refugee boys in the US (Goodman, 2004; Luster et al., 2010). Both studies on Sudanese refugee boys adopt a resilience framework. However, whereas Luster et al. focus more on successful adaption, Goodman's research interest is on culturally specific responses to trauma. Through the boys' narratives Goodman identifies four strategies designed to cope with past experiences of trauma and loss: focus on collectivity and the communal self; suppression and distraction; making meaning; and emerging from hopelessness to hope. The strategies of making meaning and focus on collectivity were also found in Luster et al.'s study, while Chase et al. put more emphas is on distraction and suppression in theirs. In these contributions to the research the children and young persons in focus are seen as active agents who in different ways are able to handle diverse situations.

\section{Conclusion}

This overview of research suggests that such studies tend to characterize unaccompanied asylum-seeking children as a particularly vulnerable category of children and therefore at risk of developing emotional problems. Their vulnerability is, according to the research, intimately linked to experiences of trauma, uprooting, loss and separation from their parents, their everyday lives and homes. Consequently they are constructed as in need of support and protection. In this context, unaccompanied children are located outside the realms of a normal - or rather ideal - childhood: i.e. within a family and characterized by stability and security. I suggest that such a characterization of unaccompanied children as particularly in need is partly linked to the nature of the research itself, which is primarily conducted within individual-oriented disciplines that focus on psychopathology and developmental perspectives. This may well have implications for how these young persons are understood and constructed as a category.

Of course, research with a focus on the individual is perfectly valid in itself. Indeed, the individually oriented studies reviewed here themselves make some important contributions to our understanding of the field. However, what this article highlights is that in some of this research there is a risk of pathologizing certain categories of individuals - in this case unaccompanied children and young persons. The research reviewed is primarily focused on the problems that unaccompanied children carry with them and on their risk of developing emotional difficulties due to these problems. There appears to be insufficient attention paid in many of the studies to situations where unaccompanied children do not develop emotional problems. It is sometimes suggested in the literature that research needs to explore protective factors among children who show resilience (e.g. Hodes et al., 2008). However, apart from the studies on coping strategies and inner resources, this is rarely done.

There may also a risk in some of the research reviewed here of othering these children and young persons as a deviant category. I suggest that this othering may partly derive from the pathologization of them as category who are at a greater risk in comparison with other children and young persons of developing emotional problems and psychiatric diagnosis. It may also be connected with some of the family-oriented perspectives of children which are adopted in much of the literature, where unaccompanied children are seen as deviant - and therefore vulnerable and at risk - because they have been separated from their parents. Moreover, there is also a risk of depicting these children as the ethnic other if cultural understandings of family are drawn upon which suggest that children from - what is referred to as - 'collectivistic cultures' may be more prone to emotional damage. With some exceptions, there is a severe lack of research paying attention to the structural conditions and processes of power, racis $m$ and social exclusion in the host country - and how these factors might affect the well-being and life situations of unaccompanied asylum-seeking children. Rather, there is a tendency to place the focus on experiences that 
unaccompanied children carry with them from their migration processes and coun tries of origin - especially separations consequent upon migration - and on their ensuing emotional problems. In this sense it could be argued that background experiences and separations are seen as the most aggravating factors in unaccompanied children's and young persons' lives. While clearly these can sometimes be relevant, such an approach may not sufficiently take into consideration the young persons' life situations in thehost country and the structural conditions they face there. In this way, unaccompanied children - as asylum-seekers and as children - are located as a category both inside and yet also outside of society.

Moreover, viewing these studies from a sociological perspective I suggest that the univocal concern in this research with emotional problems, trauma and psychiatric diagnosis also runs the risk of constructing unaccompanied children as passive and vulnerable, i.e. not seeing them as able - despite sometimes being in a vulnerableposition - and as actors in their own right. However, as this article shows, there is some literature that views unaccompanied children and young persons as capable and actors in their own right, particularly when exploring coping strategies, resilience and adaption (see Chase et al., 2008; Goodman, 2004; Luster et al., 2010). The studies have taken the voices of the children and young people concerned into account and in this way the children and young persons have contributed to the research. Nevertheless, I suggest that there still is an urgent need for research that deals with life experiences in the host country and which takes its point of departure from the unaccompanied children's and young persons' own perspectives. In particular, there is an urgent need for investigations focused on the young persons' own perspectives of well-being as well as the factors contributing to it. In addition we require research which explores how they themselves conceive of opportunities and obstacles concerning for instance the educational system, reception structure and the labour market - in the host country. Finally, further research on the concept of belonging is essential as a means of exploring the situation of unaccompanied children and young persons in the host country and their own perspectives of their position. This research needs to embrace not only how they create/maintain belonging in the host country (as well as transnationally) but also how belonging is demarcated in terms of racialized/gendered views of the other and in relation to citizenship. A combination of theoretical perspectives on structural processes together with agency oriented pers pectives should not only ensure that forthcoming research will contribute to our specific knowledge about the life situation of unaccompanied children and young persons. It will also stimulate more general sociological discussions regarding social structure, belonging and citizenship as well as the intersections of age, 'race', ethnicity and gender.

\section{Funding}

This research received no specific grant from any funding agency in the public, commercial, or not-for-profit sectors.

\section{Notes}

1. The Separated Children in Europe Programme is a joint initiative between the United Nations High Commissioner for Refugees (UNHCR) and Save the Children.

2. 'Global North' is derived from current globalization debates (Connell, 2007).

3. Concerning the situation for asylum-seeking children in general in a Nordic and European context, see among others Andersson et al. $(2005,2010)$ and Vitus (2010).

\section{References}

Alanen L (1992) Modern Childhood? Exploring the 'Child Question' in Sociology. Jyväskylä: Institute for Educational Research.

Almqvist K (1997) Refugee Children: Effects of Organized Violence and Forced Migration on Young Children's Psychological Health and Development. Göteborg: Department of Psychology, Göteborg University.

Alver BG and Øyen Ø (1997) Etik och praktik i forskarens vardag. Lund: Studentlitteratur.

Andersson HE, Ascher H, Björnberg U et al. (eds) (2005) The Asylum-Seeking Child in Europe. Göteborg: Centre for European Research, Göteborg University.

Andersson HE, Ascher H, Björnberg U et al. (eds) (2010) Mellan det förflutna och framtiden. Asylsökande barns välfärd, hälsa och välbefinnande. Göteborg: Centrum för Europaforskning, Göteborgs universitet, CERGU.

Ayotte W (2000) Separated Children Coming to Western Europe: Why They Travel and How They Arrive. London: Save the Children.

Bean TM, Derluyn I, Eurelings-Bontekoe E et al. (2007) Comparing psychological distress, traumatic stress reactions, and experiences of unaccompanied refugee minors with experiences of adolescents accompanied by parents. Journal of Nervous and Mental Disease 195(4): 288-297.

Bhabha J (1999) Out of the frying pan and into the fire? Unaccompanied child asylum seekers in the United States. Social Politics 6(2): 263-270.

Brendler-Lindqvist M and Larsson J (2004) Att möta de ensamkommande barnen. Stockholm: Rädda Barnen/Save the Children.

Chase E, Knight A and Statham J (2008) The Emotional Well-being of Young Persons Seeking Asylum in the UK. London: British Association for Adoption and Fostering (BAAF).

Chatty D, Crivello G and Hundt GL (2005) Theoretical and methodological challenges of studying refugee children in the Middle East and North Africa: Young Palestinian, Afghan and Sahrawi refugees. Journal of Refugee Studies 18(4): 387409. 
Chin E (2003) Children out of bounds in globalizing times. Postcolonial Studies 6(3): 309-325.

Connell R (2007) Southern Theory: Social Science and the Global Dynamics of Knowledge.Cambridge: Polity Press.

Derluyn I and Broekaert E (2007) Different perspectives on emotional and behavioural problems in unaccompanied refugee children and adolescents. Ethnicity and Health 12(2): 141-162.

Derluyn I and Broekaert E (2008) Unaccompanied refugee children and adolescent: The glaring contrast between a legal and a psy chological perspective. International Journal of Law and Psychiatry 31(4): 319-330.

Eide K (2000) Barn i bevegelse: Om oppvekstog levekår for enslige mindreårige flyktninger. Telemark: Avdeling for helseog sosialfag, Högskolen i Telemark.

Eide K (2005) Tvetydige barn. Om barnemigranter $i$ et historiskt komparativt perspektiv. Bergen: Universitetet i Bergen.

Freud A and Burlingham D (1943) War and Children. New York: New York Books.

Goodman J (2004) Coping with trauma and hardship among unaccompanied refugee youths from Sudan. Qualitative Health Research 14(9): 1177-1196.

Halvorsen K (2002) Separated children seeking asylum: The most vulnerable of all. Forced Migration Review 12: 34-36.

Hart R (1992) Children's Participation: From Tokenism to Citizenship. Florence: UNICEF.

Hessle M (2009) Ensamkommande men inte ensamma: tioårsuppföljning av ensamkommande asylsökande flyktingbarns livsvillkor och erfarenheter som unga vuxna i Sverige. Stockholm: Pedagogiska institutionen, Stockholms universitet.

Hjern A and Angel B (2000) Organized violence and mental health of refugee children in exile: A six-year follow-up. Acta Paediatrica 89(6): 722-727.

Hodes M, Jagdev D, Chandra N and Cunniff A (2008) Risk and resilience for psychological distress among unaccompanied asylum seeking adolescents. The Journal of Child Psychology and Psychiatry 49(7): 723-732.

Hopkins PE and Hill M (2008) Pre-flight experiences and migration stories: The accounts of unaccompanied asylum-seeking children. Children's Geographies 6(3): 257-268.

Kohli R (2005) The sound of silence: Listening to what unaccompanied asylum-seeking children say and do not say. British Journal of Social Work 36(5): 707-721.

Lomfors I (2006) Förlorad barndom, återvunnet liv: de judiska flyktingbarnen från Nazityskland. Göteborg: Historiska institutionen, Göteborgs universitet.

Luster T, Qin D, Bates L et al. (2010) Successful adaptation among Sudanese unaccompanied minors: Perspectives of youth and foster parents. Childhood 17(2): 197-211.

Qvortrup J (1985) Placing children in the division of labour. In: Close P and Collins R (eds) Family and Economy in Modern Society. London: Macmillan, pp. 129-145.

Rutter M (2002) Nature, nurture and development: From evangelism through science towards policy and practice. Child Development 73(1): 1-21.

SCEP (Separated Children in Europe Programme) (2004) Statement of Good Practice, 3rd edn. Brussels: Save the Children and UNHCR.

Sinha S, Uppal S and Pryce A (2008) Seeking sanctuary: Exploring the changing postcolonial and racialised politics of belonging in east London. Sociological Research Online 13(5): 101-110.

Sourander A (1998) Behavioural problems and traumatic events of unaccompanied refugee minors. Child Abuse and Neglect 22(7): 719-727.

Thomas S and Byford S (2003) Researching Unaccompanied Asylum Seeking Children - Ethical Issues. British Medical Journal. 327(7428): 1400-2.

Thomas S, Nafees B and Bhugra D (2004) 'I was running away from death': The pre-flight experiences of unaccompanied asy lum seeking children in the UK. Child: Care, Health and Development 30(2): 113-122.

UNHCR (1994) Refugee Children: Guidelines on Protection and Care. Geneva: United Nations High Commissioner for Refugees.

Vitus K (2010) Waiting time: The de-subjectification of children in Danish asylum centres. Childhood17(1): 26-42.

Wallin A and Ahlström G (2005) Unaccompanied young adult refugees in Sweden, experiences of their life situation and wellbeing: A qualitative follow-up study. Ethnicity and Health 10(2): 129-144.

Wrangsjö B and Winberg Salomonsson M (2007) Tonårstid. Stockholm: Natur och Kultur.

Wyness M (2006) Childhood and Society: An Introduction to the Sociology of Childhood. New York: Palgrave Macmillan. 